\title{
Chlorinated hydrocarbons in North Sea whiting (Merlangius merlangus L.), and effects on reproduction. I. Tissue burden and hatching success
}

\author{
H. v. Westernhagen ${ }^{1}$, P. Cameron ${ }^{2}$, V. Dethlefsen ${ }^{2} \&$ D. Janssen ${ }^{1}$ \\ ${ }^{1}$ Biologische Anstalt Helgoland; Notkestraße 31, D-2000 Hamburg 52, \\ Federal Republic of Germany \\ 2 Bundesforschungsanstalt für Fischerei, Institut für Küsten- und Binnenfischerei, \\ Toxikologisches Laboratorium; D-2190 Cuxhaven, Federal Republic of Germany
}

\begin{abstract}
Artificially inseminated eggs of feral North Sea whiting (Merlangius merlangus) were incubated in the laboratory in order to determine reproductive success. After incubation, two measures for reproductive success, total hatch and viable hatch, were determined and correlated with chlorinated hydrocarbon residues in the respective ovaries. From their specific toxicities and the sum of all determined chlorinated hydrocarbon contaminants, a contamination factor (CF) was calculated. Significant negative correlations were found between total hatch and DDT, including its metabolites ( $\Sigma D D T)$, dieldrin and the CF. $\Sigma D D T$ and the CF were also negatively correlated with viable hatch. A threshold value of ovary contamination above which impairment of reproductive success was likely to occur was set at $>200 \mu \mathrm{g} \mathrm{kg}^{-1}$ wet wt. for $\Sigma$ PCB, $>20 \mu \mathrm{g} \mathrm{kg}^{-1}$ wet wt. for $\Sigma$ DDT and $>10 \mu \mathrm{g} \mathrm{kg}^{-1}$ wet wt. for dieldrin.
\end{abstract}

\section{INTRODUCTION}

In the world-wide fight against pollution the environmental levels of chlorinated hydrocarbons have been considerably reduced in the aquatic environment of the northern hemisphere. In trend-monitoring studies, Olsson \& Reutergardh (1986) were able to show that in herring in the Baltic Sea area, levels of DDT started to decline between 1969 and 1972, and levels of PCBs between 1975 and 1978. A similar development has been established for pike, Esox lucius, and guillemot (eggs), Uria aalgae. Despite this general trend, levels of chlorinated hydrocarbons in the biota are still substantial. In the case of Baltic flounder, Platichthys flesus, and herring, Clupea harengus, levels of PCBs in ovaries of specimens caught in 1978 (flounder) and 1979 (herring) were high enough to cause substantial impairment of reproduction; measured as emerging larvae ("viable hatch") from artificially inseminated eggs (Westernhagen et al., 1981; Hansen et al., 1985).

Similar events have been reported for other species and areas contaminated with chlorinated hydrocarbons, notably Atlantic salmon, Salmo salar, from Sweden (Jensen et al., 1971), sea trout, Cynoscion nebulosus, from the Laguna Madre (Butler et al., 1972), rainbow trout, Salmo gairdneri, from New Zealand (Hopkins et al., 1969; Dacre \& Scott, 
1971) and from Columbia, Missouri (Hogan \& Brauhn, 1975), striped bass, Morone saxatilis, from South Carolina, USA (Westin et al., 1985) and starry flounder, (Platichthys stellatus), from San Fracisco Bay (Spies et al., 1985; Spies \& Rice, 1988). In all these cases, either hatching was reduced or did not occur at all, or the hatched larvae or alevins suffered extremely high mortality during the yolk sac stage. In the sea trout population of the Laguna Madre, recruitment failure led to the collapse of the affected stock (Butler et al., 1972). In the case of the Baltic flounder and herring investigated by us in the past (Westernhagen et al., 1981; Hansen et al., 1985), PCB- and DDE-induced reproductive impairment (viable hatch below $50 \%$ ) was only detectable in 6 out of 59 and 5 out of 74 artificially inseminated pairs of flounder and herring respectively. Thus, impairment of reproduction in terms of affected parental fish in these species was in the range of 7 to $10 \%$ of the population.

On the other hand, "in situ" investigations of naturally spawned flounder eggs from the Baltic (Westernhagen et al., 1988) showed a much higher percentage of affected embryos, i.e. more than $50 \%$ in the early developmental stages. In the southern North Sea, the phenomenon of embryo malformations has also been documented recently in several species (Dethlefsen et al., 1986). The most affected species in the German Bight was found to be the whiting (Merlangius merlangus). In the early developmental stages, between 40 and $50 \%$ of all embryos investigated were defective. Thus, with this high rate of malformation in mind and on the basis of the above mentioned findings, whiting ovaries should display high burdens of chlorinated hydrocarbons. Viable hatch in whiting eggs should be equally affected.

\section{MATERIAI AND METHODS}

\section{Incubation experiments}

In March 1984, 60 pairs of mature (running ripe) whiting (Merlangius merlangus) were caught by otter trawl in the southern North Sea off the Dutch coast in an area between $52^{\prime} 30-53^{\prime} 30^{\circ} \mathrm{N}$ and $03.00-04.00^{\circ} \mathrm{E}$. Immediately after the catch, eggs and sperm were stripped from running ripe parental fish and mixed in pre-cooled jars $\left(5^{\circ} \mathrm{C}\right)$. Then, sea water $\left(5^{\circ} \mathrm{C}_{i} \mathrm{~S}=33 \times 10^{-3}\right)$ was added and the egg/spermatic fluid mixture was allowed to stand for 10 to 15 minutes to ensure proper fertilization (see Westernhagen, 1970).

The eggs were then transferred to 500 -ml incubation jars (250-400 eggs per jar) containing $300 \mathrm{ml}$ of North Sea water, which had been taken at a station in the open North Sea and which served as "standard" incubation medium during the experiments. Incubation was carried out at $5^{\circ} \mathrm{C} \pm 0.3$ and at a salinity of $S=33 \times 10^{-3}$.

Unfertilized and dead eggs were recorded and removed daily when incubating water was changed. Percent total hatch $(\mathrm{H} / \mathrm{N} \times 100)$ and $\%$ viable hatch $(\mathrm{L} / \mathrm{N} \times 100)$ were determined at the end of each experiment on the basis of the number of normal or abnormal larvae using the following morphological criteria. Total hatch were all those larvae that had left the egg shell upon termination of the experiment. Normal individuals were those which, following anesthetization with tricaine methanesulfonate (MS 222), had straight notochords, normal eyes and mouths and no yolk defects. Abnormal individuals were those displaying scoliosis, lordosis or defective eye, mouth or yolk sac 
development. We defined the measures of eggs and larvae as follows: $\mathrm{N}=$ total number of eggs in experiment; $\mathrm{H}=$ total number of larvae that left the egg shell; $\mathrm{L}=$ number of normal larvae. The results used for interpretation were the means of two replicates.

A major source of variability in egg survival in repetitive spawning species is related to the sequence of eggs in spawning: eggs spawned first do not develop as well as those spawned last. This phenomenon is a function of the egg position in the ovarian lumen after ovulation, and may be related to the time between ovulation and stripping (Spies \& Rice, 1988). In order to minimize bias originating from this constellation a surplus of eggs was stripped from which, after mixing and fertilization, only a fraction was used for the incubation experiment. Males contribute little to the variability in fertilization success, provided they have motile sperm, as shown for flounders (Westernhagen et al., 1987; Spies \& Rice, 1988).

\section{Tissue sampling and analysis of contaminants}

For organochlorine analysis the remainder of the stripped gonads as well as the livers of both the female and the male fish used for the incubation experiments were taken. Anl tools and containers used in the preparation of samples had previously been washed in acetone and hexane. Tissue was cut from the parental fish with stainless steel tools, transferred to glass bottles closed with teflon covers and, immediately after, stored at $-25^{\circ} \mathrm{C}$ until analysis.

For the gaschromatographic analysis frozen tissue admixed with quartz sand and $\mathrm{Na}_{2} \mathrm{SO}_{4}$ was ground in an agate mortar. The resulting tissue powder was then treated with a solvent mixture of $n$-hexane and acetone $(2: 1)$ in a glass column. In order to separate the fatty components from the other organic compounds, gelpermeation chromatography and an additional clean-up process employing a silica column according to Specht \& Tilkes $(1980)$ were used. In this way, two eluates were produced, one containing PCBs, HCB, $\alpha$ - and $\gamma$-BHC (in other papers sometimes named $\mathrm{HCH}$ ), DDE, DDT, DDD, heptachlor and aldrin, while the second fraction contained dieldrin, endrin, $\alpha$-endosulfan, heptachlorepoxid, endosulfansulfate and methoxychlor.

The gaschromatograph (GC) employed for the analytical procedures was a Packard Modell 428 with ${ }^{63} \mathrm{Nickel}$ electron capture detector (ECD). Separation occurred on a $25 \mathrm{~m}$ quartz capillary with an inner diameter of $0.32 \mathrm{~mm}$. GC-working conditions were the following: Detector $=300^{\circ} \mathrm{C}$, cold on-column injection. Temperature programme: $T_{1}=$ $70^{\circ} \mathrm{C}(2 \mathrm{~min}), \mathrm{R}_{1}=5^{\circ} \mathrm{C} \mathrm{min}^{-1} ; \mathrm{T}_{2}=280^{\circ} \mathrm{C}(10 \mathrm{~min})$. For the calculation of the PCBcontent the technical mixture Clophen $\mathrm{A} 60$ was used as a PCB standard. The 4 most intensive PCB peaks of Clophen A60 (CB 118/149,153,138,180) were taken to quantify the PCB content in the fish samples. Although knowing that total PCB contains different congeners with different toxicities, this standard was used to make whiting data comparable with the contaminant concentrations as determined in older publications.

\section{Contamination factor}

In an attempt to relate the total concentration and the different toxicities of the major representatives of the chlorinated hydrocarbons to viable hatch, a "contamination factor" was introduced. This factor was determined by the concentration of the different chlori- 
nated hydrocarbons analysed in the tissue and their fish toxicity ( $96 \mathrm{~h} \mathbf{L C}_{50}$ basis) in relation to the toxicity of PCBs. PCB is used as the basis for comparisons, because it is found in every analysed sample and makes up around $50 \%$ of the total toxic load. Although all organochlorine components have different ways of acting, and reproductive success could be impaired by effects upon sexual hormones, the use of a contamination factor is an attempt not only to take single components or add all contamin ants together, but to take into consideration their different toxicities in regard to fish larval mortality. For the toxicity estimate, experimental and literature data were used from: Gagnon, 1958; Iyatomi et al., 1958; Henderson et al., 1959; Katz, 1961; Katz \& Chadwick, 1961; Cope, 1965; Andrews et al., 1966; Eisler \& Edmunds, 1966; Macek et al., 1969; Duke et al., 1970; Macek \& McAllister, 1970; Macek \& Sanders, 1970; Pimentel, 1971; Hansen et al., 1971; Merna et al., 1972; Stalling \& Mayer, 1972; Holden, 1973; Korn \& Earnest, 1974; Hansen et al., 1975; Hirose \& Kitsukawa, 1976; Macek et al., 1976a, b; Dethlefsen, 1977; Ellgaard et al., 1977; Hermanutz, 1978; Perkow, 1983 and Hansen et al., 1985. On the basis of the information drawn from the above papers, the fish toxicity of chlorinated hydrocarbons in question could be set out as follows: Endrin $=110 ; \alpha$-endosulfan and endosulfansulfate $=17.5 ; \mathrm{DDT}=9.3 ; \mathrm{DDE}=9.3$; aldrin $=7.3 ;$ dieldrin $=7.1$; heptachlorepoxid $=6.8 ;$ heptachlor $=3.4 ;$ methoxychlor $=1.8 ;$ lindane $(\gamma-\mathrm{BHC})=1.7 ;$ PCBs $=$ 1.0. Data for DDE toxicity in fish were not available, but generally the toxicity of DDE is considered to equal that of DDT (Dethlefsen, 1977), thus the value for DDT was adopted for DDE. $\alpha-B H C, D D D$ and $H C B$ were neglected since their toxicities in comparison with the other compounds mentioned are negligible (Henderson et al., 1959; Kenaga, 1966; Perkow, 1983).

On the basis of the above statements, the contamination factor (CF) was calculated as the sum of the $\mu \mathrm{g} \mathrm{kg}^{-1}$ wet wt. tissue contamination of the respective substance, multiplied by its relative toxicity. Thus $C F=P C B+110$ Endrin +17.5 ( $\alpha$-endosulfan + endosulfansulfate) + 9.3(DDT + DDE) + 7.3aldrin + 7.1dieldrin + 6.8heptachlorepoxid +3.4 heptachlor +1.8 methoxychlor +1.7 lindane.

\section{RESULTS}

\section{Accumulation of chlorinated hydrocarbons in liver and gonads}

Concentrations of chlorinated hydrocarbons in female and male gonads and livers are depicted in Table 1 and 2. Because of the low fat content in ovary and testes (1-10\%), values for these tissues are given as $\mu \mathrm{g} \mathrm{kg}^{-1}$ wet weight. Liver burdens are indicated as $\mu \mathrm{gg}^{-1}$ fat, since liver fat in whiting is high (up to $85 \%$ ).

Highest residue levels $(\bar{x})$ were determined for PCBs, followed by DDE, DDD, DDT and dieldrin as well as HCB and heptachlorepoxid. All these major contaminants occurred consistently as the main residues in ovaries and livers. In testes, contamination was low (Table 2), and the majority of the substances occurred below the limits of detection.

The levels of contamination with the different components are frequently a reflection of the biochemical processes taking place in the fish body. Metabolites as well as storage forms are generally found in higher concentrations than the original components. This is true in the case of DDT, which is degraded to DDE and DDD; aldrin is converted to its 
epoxide and analogue dieldrin, and heptachlor is transformed to heptachlorepoxide, while endosulfansulfate is the oxidized metabolite of endosulfan (Matsumura, 1976).

PCB content in ovaries ranged from 3 to $370 \mu \mathrm{g} \mathrm{kg}^{-1}$ wet weight, with a mean value of $129.0 \mu \mathrm{g} \mathrm{kg}^{-1}(\mathrm{n}=56)$. The distribution of the contamination level was shifted to the

Table 1. Concentrations of chlorinated hydrocarbons in ovary and liver of female North Sea whiting. $\overline{\mathbf{x}}=$ mean, $0=$ below detection limit

\begin{tabular}{|c|c|c|c|c|}
\hline \multirow[b]{2}{*}{ Whiting } & \multirow{2}{*}{$\begin{array}{c}\text { Ovary } \\
\mathrm{n}=56 \\
\text { Fresh weight } \\
\mu \mathrm{g} \mathrm{\textrm {kg } ^ { - 1 }}\end{array}$} & \multicolumn{3}{|c|}{$\begin{array}{c}\text { Liver } \\
\mathrm{n}=30\end{array}$} \\
\hline & & $\overline{\mathbf{x}}$ & $\begin{array}{c}\text { Fat } \\
\mu \mathrm{kg} \mathrm{k}^{-1}\end{array}$ & $\overline{\mathbf{x}}$ \\
\hline$\Sigma P C B$ & $3-370$ & 129.0 & $1318-47162$ & 9247 \\
\hline$\alpha-\mathrm{BHC}$ & $0-3$ & 0.7 & $8-\quad 149$ & 47 \\
\hline$\gamma-\mathrm{BHC}$ & $0-19$ & 1.2 & $0-\quad 162$ & 44 \\
\hline Dieldrin & $0-20$ & 3.6 & $0-1246$ & 209 \\
\hline HCB & $0-52$ & 2.6 & $11-277$ & 75 \\
\hline Heptachlorepoxid & $0-78$ & 2.2 & $0-1039$ & 121 \\
\hline Heptachlor & $0-\quad 4$ & 0.2 & $0-\quad 32$ & 1 \\
\hline Aldrin & $0-10$ & 0.8 & $0-$ & 0.3 \\
\hline Endrin & $0-1$ & 0.1 & 0 & \\
\hline$\alpha$-Endosulfan & $0-2$ & 0.1 & 0 & \\
\hline Endosulfansulfat & $0-4$ & 0.2 & $0-\quad 95$ & 3 \\
\hline $\mathrm{p}, \mathrm{p}-\mathrm{DDT}$ & $0-58$ & 3.4 & $64-2992$ & 541 \\
\hline$p, p-D D E$ & $0-41$ & 7.1 & $86-1600$ & 534 \\
\hline p.p-DDD & $0-28$ & 4.4 & $41-3254$ & 449 \\
\hline
\end{tabular}

Table 2. Concentrations of chlorinated hydrocarbons in testes and liver of male North Sea whiting. $\overline{\mathrm{x}}=$ mean, $0=$ below detection limit

\begin{tabular}{|c|c|c|c|c|}
\hline \multirow[b]{2}{*}{ Whiting } & \multirow{2}{*}{$\begin{array}{l}\text { Testes } \\
\quad \mathbf{n}=16 \\
\text { Fresh weight } \\
\mu \mathrm{g} \mathrm{kg}^{-1}\end{array}$} & \multicolumn{3}{|c|}{$\begin{array}{c}\text { Liver } \\
\mathbf{n}=18\end{array}$} \\
\hline & & $\overline{\mathbf{x}}$ & $\begin{array}{c}\text { Fat } \\
\mu \mathrm{g} \mathrm{kg^{-1 }}\end{array}$ & $\overline{\mathrm{x}}$ \\
\hline$\Sigma \mathrm{PCB}$ & $0-180$ & 52.0 & $107-38952$ & 10397 \\
\hline$\alpha-\mathrm{BHC}$ & 0 & & $0-\quad 125$ & 37 \\
\hline$\gamma-\mathrm{BHC}$ & 0 & & $0-\quad 107$ & 41 \\
\hline Dieldrin & $0-3$ & 0.3 & $0-503$ & 128 \\
\hline $\mathrm{HCB}$ & $0-20$ & 1.3 & $0-\quad 240$ & 75 \\
\hline Heptachlorepoxid & 0 & & $0-\quad 654$ & 138 \\
\hline Heptachlor & 0 & & $0-\quad 47$ & 4 \\
\hline Aldrin & 0 & & 0 & \\
\hline Endrin & 0 & & 0 & \\
\hline$\alpha$-Endosulfan & 0 & & 0 & \\
\hline Endosulfansulfat & 0 & & $0-\quad 60$ & 4 \\
\hline $\mathrm{p}, \mathrm{p}-\mathrm{DDT}$ & 0 & & $0-1303$ & 498 \\
\hline p,p-DDE & $0-6$ & 1.1 & $0-1822$ & 541 \\
\hline p,p-DDD & $0-1$ & 0.1 & $0-1404$ & 325 \\
\hline
\end{tabular}




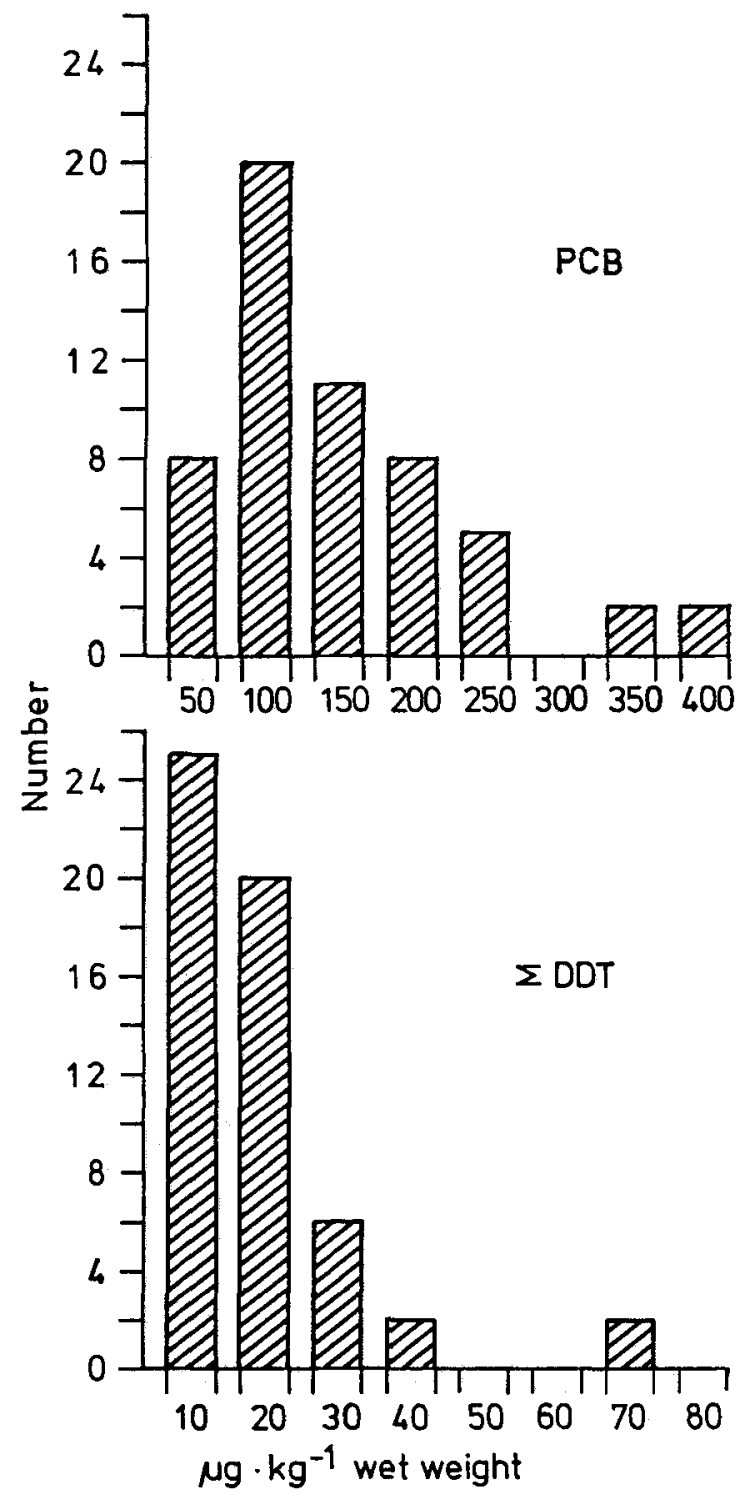

Fig. 1. Merlangius merlangus. Numerical distribution of PCB and $\Sigma D D T$ burden $\left(\mu \mathrm{g} \mathrm{kg}^{-1}\right.$ wet weight) in ovaries. $n=56$

lower ranges as shown in Figure 1. Contamination higher than $200 \mu \mathrm{gg}^{-1}$ wet weight was found in $16 \%$ of all specimens.

The contaminants second in importance were DDT and its metabolites DDD and DDE. DDT in ovaries occurred up to $58.0 \mu \mathrm{g} \mathrm{kg}^{-1}$ wet weight. Means for the members of the DDT group were between 3.4 and $7.1 \mu \mathrm{g} \mathrm{kg}^{-1}$ wet weight for DDT and DDE respectively. About $20 \%$ of the experimental animals contained more than $20 \mu \mathrm{g} \mathrm{kg}^{-1}$ 
$\Sigma$ DDT (calculated as DDT + DDD + DDE, Fig. 1) in their ovaries. Dieldrin showed a similar occurrence to that of DDT, with a mean ovary contamination level of $3.6 \mu \mathrm{g} \mathrm{kg}^{-1}$. Mean ovary contamination by all the other substances lay below $3.0 \mu \mathrm{g} \mathrm{kg}^{-1}$.

The overall contamination of livers was up to two orders of magnitude higher than that of gonads and was found to be between 646 and $13020 \mu \mathrm{g} \mathrm{kg}^{-1}$ wet weight for $\Sigma$ PCB in females (mean: $3950 \mu \mathrm{g} \mathrm{kg}^{-1}$ ) or 1318 to $47162 \mu \mathrm{g} \mathrm{kg}^{-1}$ on fat basis (mean: $9247 \mu \mathrm{g}$ $\mathrm{kg}^{-1}$, Table 1, $\mathrm{n}=30$ ). Male livers displayed similar PCB contamination with 63 to 12473 $\mu \mathrm{gg}^{-1}$ on wet weight or 107 to $38952 \mu \mathrm{g} \mathrm{kg}^{-1}$ on fat basis; with mean values of 4530 or $10397 \mu \mathrm{g} \mathrm{kg}^{-1}$ respectively (Table $2, \mathrm{n}=18$ ). The numerical distribution of the PCB burden in the experimental fish is depicted in Figure 2. As shown for ovary contamination, extreme values were relatively rare.

The high ranges in contaminant concentration correspond to results obtained in former investigations on flounder, Platichthys flesus, (Westernhagen et al., 1981) and herring, Clupea harengus, (Hansen et al., 1985) derived from the Baltic. These high ranges can either be the results of different exposure to sea water or food contaminant

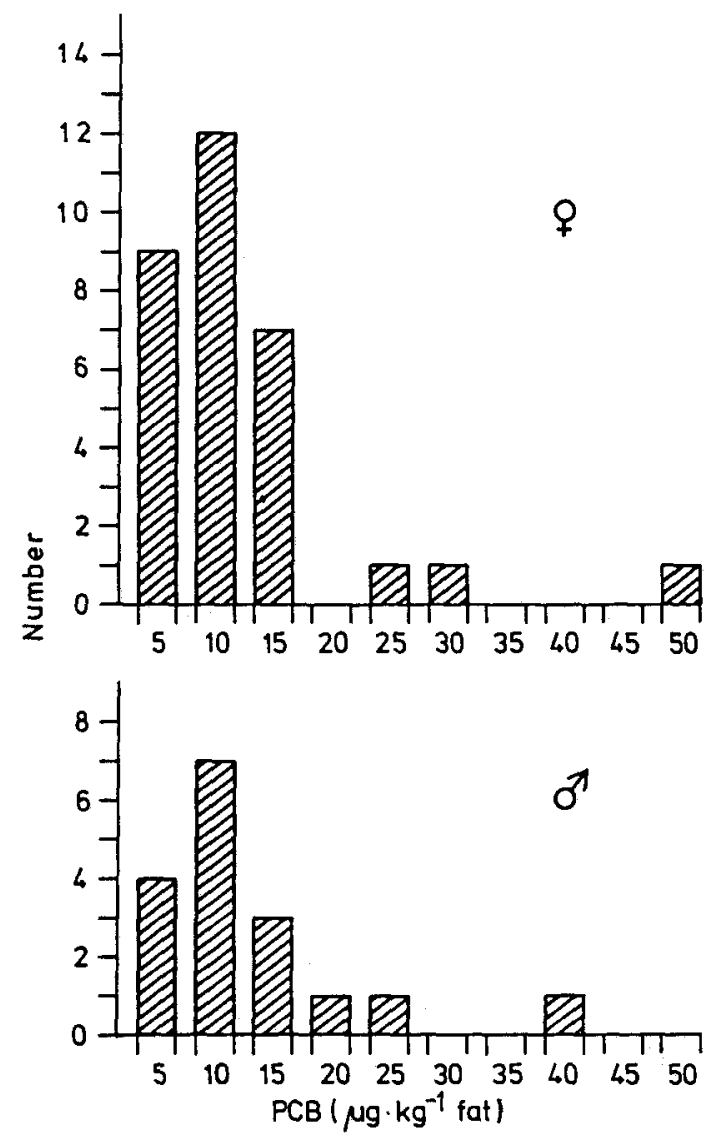

Fig. 2. Merlangius merlangus. Numerical distribution of PCBs in livers, fat basis. Female: $\mathrm{n}=30$; male: $\mathrm{n}=18$ 
concentration or they may as well reflect different biochemical or physiological individual responses to equal environmental stress. Whatever the reason for contamination, whether the fish originates from an extremely polluted area or whether it accumulates a particularly high concentration of the pollutant, important for hatching success is the ultimate concentration in the fish.

As suggested by Holden (1972), there is a tendency for high DDT and PCB values to occur together in the same individual. Drescher et al. (1977) found a positive correlation for both organochlorines in the blubber of the Harbour seal, Phoca vitulina, from the German North Sea coast. Such a relationship between PCB and total DDT values can also be deduced from the data in Figure 3 . The regression equation for PCB and total DDT concentrations in whiting ovaries is $\mathrm{Y}=0.472+0.1122 \mathrm{x}$, and the correlation coefficient amounts to 0.70 . A similar situation prevails for the relation of dieldrin to $\mathrm{PCB}$ as well as to $\Sigma$ DDT.

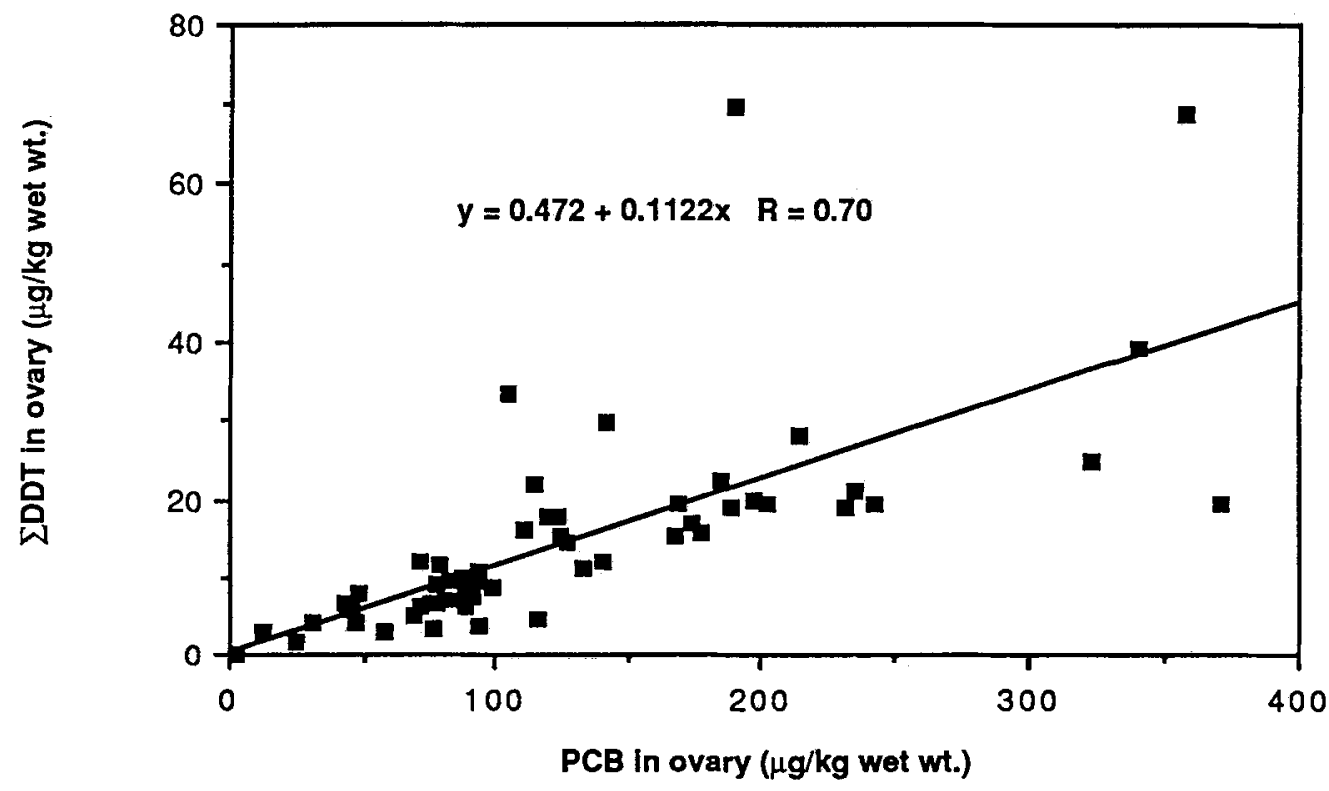

Fig. 3. Merlangius merlangus. Relation between PCB and total DDT content in ovaries $\left(\mu \mathrm{g} \mathrm{kg}^{-1}\right.$ wet weight)

\section{Gonad burden and hatching success}

Total hatch varied between 0 and $72 \%$, while viable hatch was considerably lower; highest values being just above $50 \%$. The majority of the incubated egg lots yielded below $10 \%$ viable hatch only (Fig. 4), indicating a rather poor quality of the incubated egg material. When trying to correlate tissue contamination with total and viable hatch, we realized that there was a significant negative correlation between ovary burden of $\Sigma \mathrm{DDT}(\Sigma \mathrm{DDT}=\mathrm{DDT}+\mathrm{DDD}+\mathrm{DDE})$ and total as well as viable hatch (Table 3). Dieldrin content of ovaries likewise showed a significant negative correlation with total hatch. On 
the other hand, contamination of ovaries with $\Sigma$ PCB did not show a significant correlation with either total or viable hatch (Table 3).
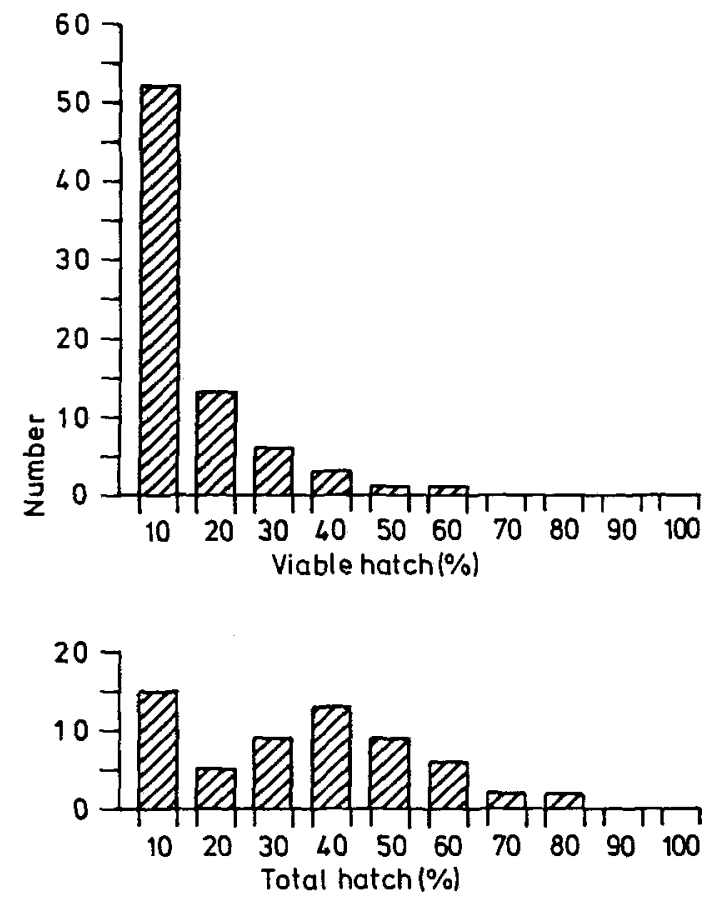

Fig. 4. Merlangius merlangus. Hatching distribution in artificially inseminated and incubated eggs. Figures indicate "less than". Temperature: $5^{\circ} \mathrm{C}$; salinity: $30 \times 10^{-3} ; \mathrm{n}=60$

Although the scatter of the data on hatching was considerable it could be seen that highly contaminated ovaries with $>20 \mu \mathrm{g} \mathrm{kg}^{-1}$ wet wt. $\Sigma D D T$, and $>10 \mu \mathrm{g} \mathrm{kg}^{-1}$ wet wt. dieldrin always occurred with viable hatch below the $10 \%$ mark (Fig. 5). This was true even in the case of high $\Sigma$ PCB concentrations (higher than $200 \mu \mathrm{g} \mathrm{kg}^{-1}$ wet wt. $\Sigma$ PCB; Fig. 5), suggesting that these values may represent a threshold for successful embryonic development. Liver and testes contamination did not show any correlation with total or viable hatch.

In order to assess any possible additive effect of all accumulated toxicants on hatching success, the contamination factor (CF) $\left(\mu \mathrm{g} \mathrm{kg}^{-1}\right.$ wet weight of toxicant multiplied by its relative toxicity) was plotted against hatching. There was the same pattern for the relation of the contamination factor to total and viable hatch as found for the $\Sigma D D T$, dieldrin and the PCBs. The negative effects of the overall contamination of the ovaries on total hatch were highly significant, those for viable hatch were significant (Table 3 ). Ovaries with a CF $>400$ only produced low viable hatch (Fig. 6).

Even though some of the contaminants contributed substantially to the contamination factor, PCBs made up around $50 \%$ of the total toxic load in female gonad tissue 
Table 3. Merlangius merlangus. Correlation between hatching success (total and viable hatch \%) and tissue burdens (contaminant concentrations and contamination factor [CF]) in ovaries of whiting off the Dutch coast. \% hatch were arcsin-transformed before regression. r: correlation coefficient; P: probability; ": significant; " : highly significant; $\mathrm{n}=54$

\begin{tabular}{|c|c|c|}
\hline & Total hatch & Viable hatch \\
\hline \multicolumn{3}{|c|}{$\Sigma \mathrm{DDT}$} \\
\hline I & -0.36 & -0.29 \\
\hline $\mathrm{p}$ & $<0.01^{\circ}$ & $<0.05^{*}$ \\
\hline \multicolumn{3}{|c|}{ Dieldrin } \\
\hline I & -0.31 & -0.19 \\
\hline $\mathrm{p}$ & $<0.05^{\circ}$ & $>0.05$ \\
\hline \multicolumn{3}{|c|}{$\Sigma$ PCB } \\
\hline $\mathbf{r}$ & -0.20 & -0.17 \\
\hline $\mathrm{p}$ & $>0.05$ & $>0.05$ \\
\hline \multicolumn{3}{|c|}{ CF } \\
\hline$r$ & -0.36 & -0.28 \\
\hline $\mathrm{p}$ & $<0.01^{\cdots}$ & $<0.05^{*}$ \\
\hline
\end{tabular}

(Fig. 7), being the most prominent single contaminant in whiting ovaries. The situation was similar in female liver tissues (Fig. 7) with a large percentage of PCBs $(43 \%)$ contributing to the contamination factor.

\section{DISCUSSION}

In laboratory experiments, chlorinated hydrocarbons have long been shown to adversely affect reproduction in fish. For example; the flatfish Pseudopleuronectes americanus exposed to DDT and dieldrin before spawning produced eggs that exhibited decreasing fertilization success with increasing dieldrin concentrations (Smith \& Cole, 1973). Direct effects of DDT and its metabolites on developing cod eggs (Gadus morhua) have been demonstrated by Dethlefsen (1977). Threshhold values for contaminants, for instance PCBs, used in laboratory exposures have been relatively high. For example in Cyprinodon variegatus, concentrations of Aroclor $1254 \mathrm{up}$ to $28000 \mu \mathrm{g} \mathrm{kg}^{-1}$ had no apparent effect on percentage of hatched eggs (Hansen et al., 1974). In brook trout, Salvelinus fontinalis, $78000 \mu \mathrm{g} \mathrm{kg}^{-1}$ Aroclor 1254 were needed in the eggs to reduce hatching from $92 \%$ to $72 \%$ in treated eggs (Freeman \& Idler, 1975).

However, the data presented in this paper indicate that chlorinated hydrocarbons accumulated in ovaries of North Sea whiting exert significant negative effects on embryonic development and production of normal larvae at relatively low tissue concentrations. Thus, for the major contaminants $\Sigma D D T$, dieldrin and $\Sigma P C B$ threshold values higher than 20,10 and $200 \mu \mathrm{g} \mathrm{kg}^{-1}$ wet wt. respectively impeded reproduction considerably (viable hatch below $10 \%$ ).

The low effective level of contaminants on reproductive success in feral marine fish has already been noticed in earlier studies on Baltic flounder, Platichthys flesus, and Baltic herring, Clupea harengus (Westernhagen et al., 1981; Hansen et al., 1985). In herring, viable hatch was significantly reduced at $\mathrm{PCB}$ and DDE concentrations higher 

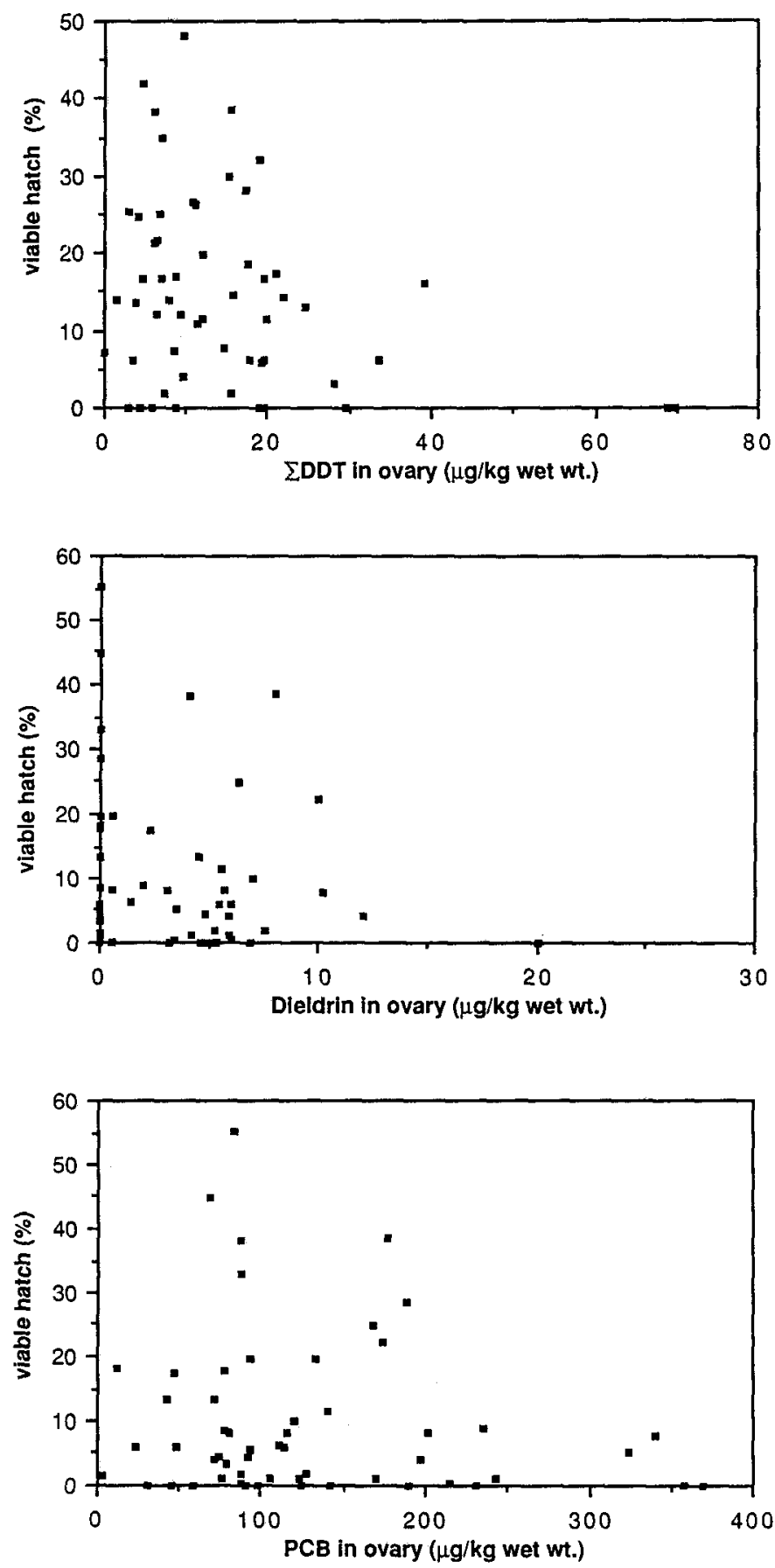

Fig. 5. Merlangius merlangus. Viable hatch (\%) of whiting eggs in relation to $\Sigma$ DDT, dieldrin and PCB content ( $\mu \mathrm{g} \mathrm{kg}^{-1}$ wet weight) of ovaries. Temperature: $5^{\circ} \mathrm{C}$; salinity: $30 \times 10^{-3} ; \mathrm{n}=59$ 


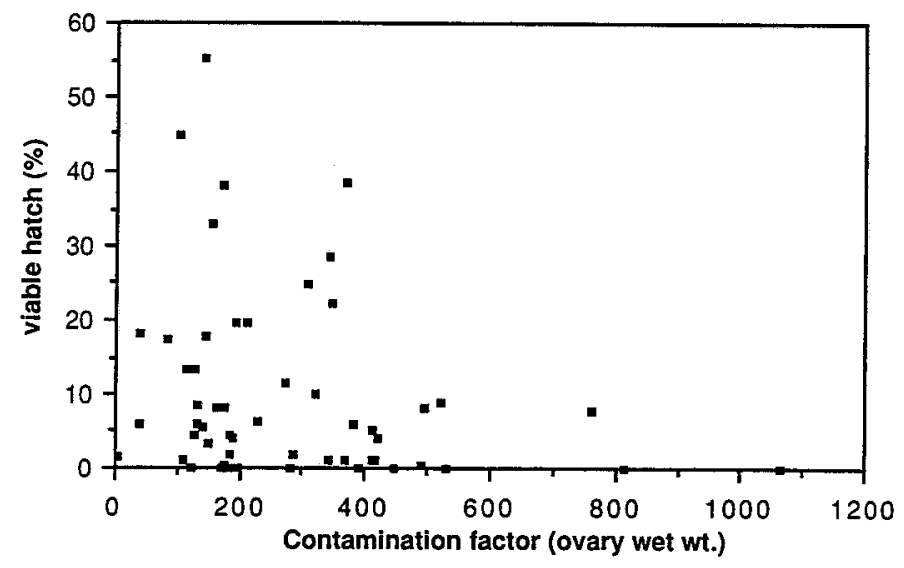

Fig. 6. Merlangius merlangus. Viable hatch (\%) of whiting eggs in relation to the contamination factor (CF) on fresh weight basis. For explanation of CF see "Materials and Methods"

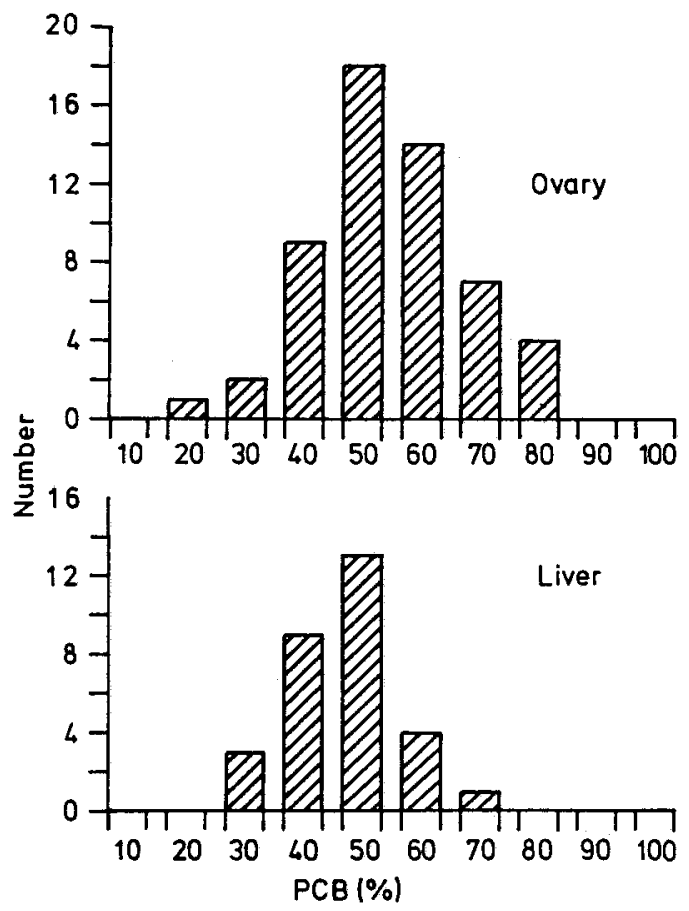

Fig. 7. Merlangius merlangus. Percent PCBs of the contamination factor (CF) of female whiting gonads and livers. Figures indicate "less than". For explanation of CF see "Material and Methods"

than 120 or $18 \mu \mathrm{g} \mathrm{kg}^{-1}$ wet wt. in ovaries respectively. For PCB in flounder ovaries the same threshold value was found. The work of Spies et al. (1985) and Spies \& Rice (1988) on starry flounder, Platichthys stellatus, from San Francisco Bay also showed that at concentrations $>12-20000 \mu \mathrm{g} \mathrm{kg}^{-1} \Sigma \mathrm{PCB}$ on lipid basis in eggs (corresponding to about 
120-200 $\mathrm{g} \mathrm{kg} \mathrm{k}^{-1}$ wet wt.), embryological success (equal to total hatch in the present paper) was reduced significantly.

The data from Table 3 suggest that as far as sensitivity of a parameter is concerned, total hatch may be a more sensitive measure than viable hatch, even though viable hatch may be the more meaningful measure in terms of biological significance, i.e. survival of the species. In incubation experiments with starry flounder, Spies \& Rice (1988) had the same results. While in their studies embryological success was highly significantly negatively correlated with total PCB in eggs, viable hatch was not.

In terms of workability of the method, the application of a contamination factor (CF) may be the more useful approach for determining the contamination load imposed on an individual. It takes into consideration the occasional occurrence of some more "exotic" contaminants, which may be toxic, and the inclusion of the respective fish in the contaminated group yielding low hatching success. Table 3 as well as Figure 5 show that in the present experiments $\Sigma$ DDT and dieldrin were the more effective substances compared to PCBs. Although PCBs make up around $50 \%$ of the CF in the ovary (Fig. 7), their effect on reproduction is relatively limited. The correlation between hatching success and contamination factor (CF) even increases when PCB content is taken out. When $\Sigma D D T$ and dieldrin are eliminated from the calculation of a CF, this leads to a decrease of the correlation coefficient, pointing towards the higher effectiveness of the latter substances.

Similar results have been obtained in Baltic herring, where the effects of DDE on viable hatch were 10 times those of PCBs (Hansen et al., 1985). Still, the effects of PCBs must not be underestimated. In female whiting about $25 \%$ of all individuals analysed contained more than $6000 \mu \mathrm{g} \mathrm{kg}^{-1}$ PCBs in gonads (on fat basis), a level above which severe mortalities of egg and fry are known to occur in Atlantic salmon hatcheries (Jensen et al., 1971; Zitko \& Saunders, 1979). In our studies conducted earlier (Westernhagen et al., 1981; Hansen et al., 1985), PCBs were effęctive and so was DDE. Spies \& Rice (1988) in their experiments with starry flounder proved PCBs to be significantly correlated with embryonic success, but not the other contaminants such as $\mathrm{DDDT}$, hexachlorbenzene or phtalate esters as measured in the spawned eggs.

The concentrations of chlorinated hydrocarbons associated with negative effects in this and other studies show that reproductive problems may be associated with only moderate environmental concentrations. One of the more disquieting and alarming pieces of information gained from this and other studies is that the effective substances to date are those which, even though their production has for several years been discontinued ( $\mathrm{PCB}, \mathrm{DDT}$ ), still linger about in the environment, able to exert their detrimental effects on the biota.

In North Sea whiting, viable hatch was generally well below values registered for other marine species (Westernhagen et al., 1981; Hansen et al., 1985); highest recorded viable hatch being just above $50 \%$. The appearance of the distribution, therefore, resembled that of the data obtained from flounder and herring incubation mentioned earlier, with low viable hatch at high contaminant concentrations or contamination factors $(C F)$. The question why the overall hatch was so low is difficult to answer. The contaminants routinely determined by us in the ovaries cannot readily be made responsible for this phenomenon, since ovary contamination of whiting equalled that of flounder and herring (Westernhagen et al., 1981; Hansen et al., 1985) with the exception of the values 
for heptachlorepoxide and HCB which were higher in whiting; HCB, however, exibited very low toxicity (Perkow, 1983). However, the contamination of whiting liver was consistently higher than that of flounder and herring from the above mentioned investigations. A high liver burden "per se" does not explain the exceptionally low hatching success, assuming that egg quality is determined in the ovary and not in the liver. Even though a transfer of contaminants from the livers (as well as from other storage sites) to the gonads probably does occur before the reproductive season when highly energetic material is stored in the eggs (Burdick et al., 1964; Butler et al., 1972; Guiney et al., 1979), ultimate gonad contamination in whiting did not reach levels beyond those discussed already for other feral marine fish. Perhaps whiting is a particularly sensitive species, as far as its reproductive phase is concerned, since as early as 1950 Messtorf (1950) reported difficulties in the artificial incubation of whiting eggs, when repetitive incubation experiments were unsuccessful.

The fact that a large number of low hatch events cannot be explained by simultaneously occurring high concentrations of the contaminants determined by us (Fig. 5) suggests that aside from these an additional array of substances may be responsible for the impairment of reproduction. Among others, phthalic esters as found in high concentrations in surface microlayer (Westernhagen et al., 1987) or polyaromatic hydrocarbons, as suggested by Spies \& Rice (1988), but which were not determined by us, may have been responsible for the unusually low viable hatch in the whiting incubation experiments. Further detailed chemical analyses will be required if all substances potentially responsible for reproductive impairment are to be discovered.

This article contains parts of a doctoral study by P. Cameron in the Faculty of Biology, Hamburg University.

\section{LITERATURE CITED}

Andrews, A. K., van Valin, C. C. \& Stebbings, B. E., 1966. Some effects of heptachlor on bluegills (Lepomis macrochirus). - Trans. Am. Fish. Soc. 95, 297-309.

Burdick, G. E., Harris, E. J., Dean, H. J., Walker, T. M., Skea, J. \& Colby, D., 1964. The accumulation of DDT in lake trout and the effect on reproduction. - Trans. Am. Fish. Soc. 93, 127-136.

Butler, P. A., Childress, R. \& Wilson, A. J., 1972. The association of DDT residues with losses in marine productivity. In: Marine pollution and sea life. Ed. by M. Ruivo. Fishing News Books, London, 262-266.

Cope, O. B., 1965. Sport fishery investigations, - Circ. U.S. Fish. Wildl. Serv. 226, 51-63.

Dacre, J. C. \& Scott, D., 1971. Possible DDT mortality in young rainbow trout. - N. Z. Jl mar. Freshwat. Res. 5, 58-65.

Dethlefsen, V., 1977. The influence of DDT and DDE on the embryogenesis and the mortality of larvae of cod (Gadus morhua L.). - Ber. dt. wiss. Kommn Meeresforsch. 25, 115-148.

Dethlefsen, V., Cameron, P., Westernhagen, H. von \& Janssen, D., 1986. Morphologische und chromosomale Untersuchungen an Fischembryonen der südlichen Nordsee in Zusammenhang mit der Organochlorkontamination der Elterntiere. - Veröff. Inst. Küst- u. Binnenfisch. 96, 1-57.

Drescher, H. E., Harms, U. \& Huschenbeth, E., 1977. Organochlorines and heavy metals in the Harbour seal Phoca vitulina from the German North Sea Coast. - Mar. Biol. 41, 99-106.

Duke, T. W., Lowe, J. C. \& Wilson, A. J., 1970. A polychlorinated biphenyl (Aroclor 1254) in the water, sediment, and biota of Escambia Bay, Florida. - Bull. environ. Contam. Toxicol. 5, 171-180.

Eisler, R. \& Edmunds, P. H., 1966. Effects of endrin on blood and tissue chemistry of a marine fish. Trans. Am. Fish. Soc. 95, 153-159. 
Ellgaard, E. G., Ochsner, J. C. \& Cox, J. K., 1977. Locomotor hyperactivity induced in the bluegill sunfish, Lepomis macrochirus, by sublethal concentrations of DDT. - Can. J. Zool. 55, 1077-1081.

Freeman, H. C. \& Idler, D. R., 1975. The effect of polychlorinated biphenyl on steroidogenesis and reproduction in the brook trout (Salvelinus fontinalis). - Can. J. Biochem. 53, 666-670.

Gagnon, A, 1958. La toxicité du DDT pour le saumon de l'Atlantique (Salmo salar Linné) et les alevins de truite (Salvelinus fontinalis Mitchell). - Can. J. Zool. 36, 479-487.

Guiney, P. D., Melancon, M. J., Lech, J. J. \& Peterson, R. E., 1979. Effects of egg and sperm maturation and spawning on the distribution and elimination of a polychlorinated biphenyl in rainbow trout (Salmo gairdneri). - Toxicol. appl. Pharmacol. 47, 261-272.

Hansen, D. J., Parrish, P. R., Lowe, J. C., Wilson, A. J. \& Wilson, P. D., 1971. Chronic toxicity, uptake and retention of Aroclor 1254 in two estuarine fishes. - Bull. environ. Contam. Toxicol. 6, 113-119.

Hansen, D. J., Schimmel, S. C. \& Forester, J., 1974. Aroclor 1254 in eggs of sheepshead minnows: effect on fertilization success and survival of embryos and fry. - Proc. a. Conf. southeastern Ass. Game Fish Commn 27, 420-426.

Hansen, D. J., Schimmel, S. C. \& Forester, J., 1975. Effects of Aroclor 1016 on embryos, fry, juveniles, and adults of sheepshead minnows (Cyprinodon variegatus). - Trans. Am. Fish. Soc. 104, $584-588$.

Hansen, P.-D., Westernhagen, H. von \& Rosenthal, H., 1985. Chlorinated hydrocarbons and hatching success in Baltic herring spring spawners. - Mar. environ. Res. 15, 59-76.

Henderson, C., Pickering, Q. H. \& Tarzwell, C. M., 1959. The relative toxicity of ten chlorinated hydrocarbon insecticides to four species of fish. - Trans. Am. Fish. Soc. 88, 23-32.

Hermanutz, R. O., 1978. Endrin and malathion toxicity to flagfish (Jordanella floridae). - Archs environ. Contam. Toxicol. 7, 159-168.

Hirose, K. \& Kitsukawa, M., 1976. Acute toxicity of agricultural chemicals to seawater teleosts, with special respect to TLm and the vertebral abnormality. - Bull. Tokai reg. Fish. Res. Lab. 84, 11-20.

Hogan, J. W. \& Brauhn, J. L., 1975. Abnormal rainbow trout fry from eggs containing high residues of a PCB (Aroclor 1242). - Progve Fish Cult. 37, 229-230.

Holden, A. V., 1972. Monitoring organochlorine contamination of the marine environment by the analysis of residues in seals. In: Marine pollution and sea life. Ed. by M. Ruivo. Fishing News Books, London, 266-272.

Holden, A. V., 1973. Effects of pesticides on fish. In: Environmental pollution and pesticides. Ed. by C. A. Edwards. Plenum Press, London, 213-253.

Hopkins, C. L., Solly, S. R. B. \& Ritchie, A. R., 1969. DDT in trout and its possible effect on reproductive potential. - N. Z. J1 mar. Freshwat. Res. 3, 220-229.

Iyatomi, K., Tamura, T., Itazawa, Y., Hanyu, I. \& Sugiura, S., 1958. Toxicity of endrin to fish. - Progve Fish Cult. 20, 155-162.

Jensen, S., Johansson, N. \& Olsson, M., 1971. PCB - indications of effects on fish. - Proc. PCB Conf. Stockholm. Rep. Swed. Salmon Res. Inst., 58-68.

Katz, M., 1961. Acute toxicity of some organic insecticides to three species of salmonids and to the threespine stickleback. - Trans. Am. Fish. Soc. 90, 264-268.

Katz, M. \& Chadwick, G. C., 1961. Toxicity of endrin to some Pacific northwest fishes. - Trans. Am. Fish. Soc. $90,394-397$.

Kenaga, E. E., 1966. Pesticide reference standards of the Entomological Society of America. - Bull. ent. Soc. Am. 12, 117-127.

Korn, S. \& Earnest, R., 1974. Acute toxicity of twenty insecticides to striped bass, Morone saxatilis. Calif. Fish Game 60, 128-131.

Macek, K. J. \& McAllister, W. A., 1970. Insecticide susceptibility of some common fish family representatives. - Trans. Am. Fish. Soc. 99, 20-27.

Macek, K. J. \& Sanders, H. D., 1970. Biological variation in the susceptibility of fish and aquatic invertebrates to DDT. - Trans. Am. Fish. Soc. 99, 89-90.

Macek, K. J., Hutchison, C. \& Cope, O. B., 1969. The effects of temperature on the susceptibility of bluegills and rainbow trout to selected pesticides, - Bull. environ. Contam. Toxicol, 4, 174-183.

Macek, K. J., Lindberg, M. A., Sauter, S., Buxton, K. S. \& Costa, P. A., 1976a. Toxicity of four pesticides to water fleas and fathead minnows. - Rep. U.S. Dept. Commerce nat. tech. Inf. Serv. EPA 600/3-76-099, 1-57. 
Macek, K. J., Buxton, K. S., Derr, S. K., Dean, J. W. \& Sauter, S., 1976 b. Chronic toxicity of lindane to selected aquatic invertebrates and fishes. - Rep. U.S. Dept. Commerce nat. tech. Inf. Serv. EPA $600 / 3-76-046,1-49$.

Matsumura, F., 1976. Toxicology and insecticides. Plenum Press, New York, 503 pp.

Merna, J. W., Bender, M. E. \& Novy, J. R., 1972. The effects of methoxychlor on fishes. I. Acute toxicity and break down studies. - Trans. Am. Fish. Soc. 101, 298-301.

Messtorf, J., 1950. Untersuchungen über die Biologie des Wittlings Merlangius merlangus (L.) in der Nordsee. - Ber. dt. wiss. Kommn Meeresforsch. 15, 277-334.

Olsson, M. \& Reutergardh, L., 1986. DDT and PCB pollution trends in the Swedish aquatic environment. - Ambio 15, 103-109.

Perkow, W., 1983. Wirksubstanzen der Pflanzenschutz- und Schädlingsbekämpfungsmittel. Parey, Berlin (Losebl.Samml.).

Pimentel, D., 1971. Ecological effects of pesticides on non-target species. Government Printing Office, Washington, D.C., $220 \mathrm{pp}$.

Smith, R. M. \& Cole, C. F., 1973. Effects of egg concentrations of DDT and Dieldrin on development in winter flounder (Pseudopleuronectes americanus). - J. Fish. Res. Bd Can. 30, 1894-1898.

Specht, W. \& Tillkes, M., 1980. Gaschromatographische Bestimmung von Rückständen an Pflanzenbehandlungsmitteln nach Clean-up über Gelchromatographie und Mini-Kieselgel-Säulenchromatographie. 2. Mitteilung: Bestimmung der Fungizide Bitanol, Fluotrimazol, Fuberidazol, Imazalil, Rabenzazole, Triadimefon und Tridimenol in Pflanzen und Boden. - Pflanzenschutznachr. Bayer 33, 61-85.

Spies, R. B. \& Rice, D. W., 1988. Effects of organic contaminants on reproduction of the starry flounder Platichthys stellatus in San Francisco Bay. II. Reproductive success of fish captured in San Francisco Bay and spawned in the laboratory. - Mar. Biol. 98, 191-200.

Spies, R. B., Rice, D. W., Montagna, P. A. \& Ireland, R. R., 1985. Reproductive success, xenobiotic contaminants and hepatic mixed-function oxidase (MFO) activity in Platichthys stellatus populations from San Francisco Bay. - Mar. environ. Res. 17, 117-121.

Stalling, D. L. \& Mayer, F. L., 1972. Toxicities of PCBs to fish and environmental residues. - Environ. Hlth Perspect. 1, 159-164.

Westernhagen, H. von., 1970. Erbrütung der Eier von Dorsch (Gadus morhua), Flunder (Pleuronectes flesus) und Scholle (Pleuronectes platessa) unter kombinierten Temperatur- und Salzgehaltsbedingungen. - Helgoländer wiss. Meeresunters. 21, 21-102.

Westernhagen, H. von, Rosenthal, H., Dethlefsen, V., Ernst, W., Harms, U. \& Hansen, P.-D., 1981. Bioaccumulating substances and reproductive success in Baltic flounder Platichthys flesus. Aquat. Toxicol. 1, 85-99.

Westernhagen, H. von, Dethlefsen, V., Cameron, P. \& Janssen, D., 1987. Chlorinated hydrocarbon residues in gonads of marine fish and effects on reproduction. - Sarsia 71, 419-422.

Westernhagen, H. von, Dethlefsen, V., Cameron, P., Berg, J, \& Fürstenberg G., 1988. Developmental defects in pelagic fish embryos from the western Baltic. - Helgoländer Meeresunters. 42, 13-36.

Westin, D. T., Olney, C. E. \& Rogers, B. A., 1985. Effects of parental and dietary organochlorines on survival and body burdens of striped bass larvae. - Trans. Am. Fish. Soc. 114, 125-136.

Zitko, V. \& Saunders, R. L., 1979. Effect of PCBs and other organochlorine compounds on the hatchability of Atlantic salmon (Salmo salar) eggs. - Bull. environ. Contam. Toxicol. 21, 125-130. 